\title{
Gas Flaring and its Implication for Environmental Accounting in Nigeria
}

\author{
AYOOLA Tajudeen John \\ Dept. of Management \& Accounting, Faculty of Administration \\ Obafemi Awolowo University, Ile-Ife, Nigeria \\ Tel: 234-80-3706-8603Ｅ-mail: alabiayoolaaca@oauife.edu.ng
}

Received: May 31, 2011

Accepted: July 17, 2011

doi:10.5539/jsd.v4n5p244

\begin{abstract}
The study examines the theoretical framework for gas flaring and its implication for environmental accounting in the Nigerian Petroleum Industry. Data were sourced from the annual reports of companies involved in gas flaring in the oil and gas industry and the result reveals that the issue plaguing environmental accounting disclosures relate to lack of a standardized requirement for disclosure, political will for legislation, enforcement and the allocation of environmental costs, therefore, the study recommends the development of an integrated corporate environmental policy with legal backing that will streamline environmental information disclosures in annual accounts
\end{abstract}

Keywords: Gas flaring, Greenhouse gases, Environmental accounting, Oil companies, Petroleum industry

\section{Introduction}

Nigeria's proven natural gas reserves are estimated at 174 trillion cubic feet(cf), with energy content slightly greater than the country's oil reserves, hence, at existing rates of production, oil reserves should last for another 37 years while gas reserves should hold out for 110 years at least. This statistics demonstrates the fact that the nation is a gas rich economy; however, out of the $5.78 \mathrm{~mm}$ cf of gas produced per day, $80 \%$ of it is flared while $12 \%$ is re-injected to enhance oil production. This leaves the nation utilizing only about $8 \%$ of its produced gas for both domestic and industrial uses as well as for export. Report has it that Nigeria ranked $2^{\text {nd }}$ after Russia in gas flaring in the world with about 23.0 billion $\mathrm{m}^{3}$ gas flared which was sufficient to meet substantial portion of Africa energy needs (World Bank, 2002). According to a World Bank sponsored study, gas flaring is one such anthropogenic activity that is defined as the "wasteful emission of greenhouse gases (GHGs) that causes global warming, disequilibrium of the earth, unpredictable weather changes and major natural disasters because it emits a cocktail of benzene and other toxic substances that are harmful to humans, animals, plants and the entire physical environment. In combustion, gaseous hydrocarbons react with atmospheric oxygen to form carbon dioxide $\left(\mathrm{CO}_{2}\right)$ which in addition to other GHGs are responsible for changes in global climate that are resulting in increasingly frequent and intense natural disasters and the spread to temperate regions of diseases once found only in the tropics.

Consequent upon this understanding, the concern for the environment has been repeatedly expressed over the years in a series of international summits and consensus like the 1997 Kyoto Protocol, Global Initiative for Gas Flaring Reduction and lately the 2007 Bali Declaration, e.t.c. While for most part of the developed countries of the world, environmental accounting and reporting has developed voluntarily (Uwalomwa \& Uadiale, 2011), however, this is not the same in developing countries ( Azzone, Manzini \& Noci, 1996). Nigeria has not been an exception in paying lip- service to issue of gas flaring as demonstrated by successive extension of gas flaring deadline many times namely 2004, 2007, 2008, 2010 and lately December $31^{\text {st }}, 2012$ as the terminal date for gas flaring by the legislative, hence the need for a reporting framework.

The objective of the study is to present environmental accounting and reporting practices of oil and gas companies in both the upstream and downstream sectors of the Nigerian Petroleum Industry. The study covers the following specific objectives:

$>$ Investigate the current status of environmental reporting practice among corporations;

$>$ Examine the level of disclosure of environmental information; and

$>$ Proffer global best practices for gas flaring accounting and reporting in the Nigerian

Oil and Gas Industry. 


\section{Nigeria's Responses to Environmental Issues}

There have been many consensuses on environmental issue internationally, some of which are:

$>$ The 1997 Kyoto Protocol

Dorld Bank Global Gas Flaring Reduction (GGFR) Public-Private Partnership, 2002

> 2007 Bali Climate Declaration by Scientists

The following initiatives are some of the responses made by Nigeria to safeguard the environment against degradation:

$>$ Associated Gas Re-injection Act Cap 26, LFN 1990 and its attendant regulations

$>$ The Oil in Navigable Waters Act Cap 331, LFN 1990 and its attendant regulations

$>$ The Oil Terminal Dues Act Cap 339, LFN 1990

$>$ Associated Gas Re-injection Act Cap 26, LFN 1990 and its attendant regulations

$>$ The Federal Environment Protection Agency Act Cap, 131 LFN 1990

$>$ Statement of Accounting Standards (SAS) 14 and 17 which regulate both the upstream and downstream sectors of the petroleum industry

$>$ Companies and Allied Matters Act, (CAMA) 1990

$>$ Security and Exchange Commission (SEC) Code of Corporate Governance, 2008

$>$ Nigerian Gas Master Plan, 2008 which is a guide for the commercial exploitations and management of Nigeria's gas sector aimed at growing the economy with gas

> Final Deadline on Gas Flaring: The Nigerian legislative arm has finally chosen 31st

\section{Methodology} December, 2012 as deadline for gas flaring fully backed up by the law.

The primary purpose of this paper is to examine the theoretical framework for gas flaring and its implication for environmental accounting. The study focuses exclusively on selected oil and gas companies in both the upstream and downstream sector of the Nigerian petroleum industry. The empirical study is therefore based on 10 companies selected through convenient sampling method. Data were sourced through interviews granted under strict condition of anonymity and content analysis of annual reports and/or environmental reports.

The following survey reports were used as reference and served as the basis for the development of an evaluation method. The survey reports included:

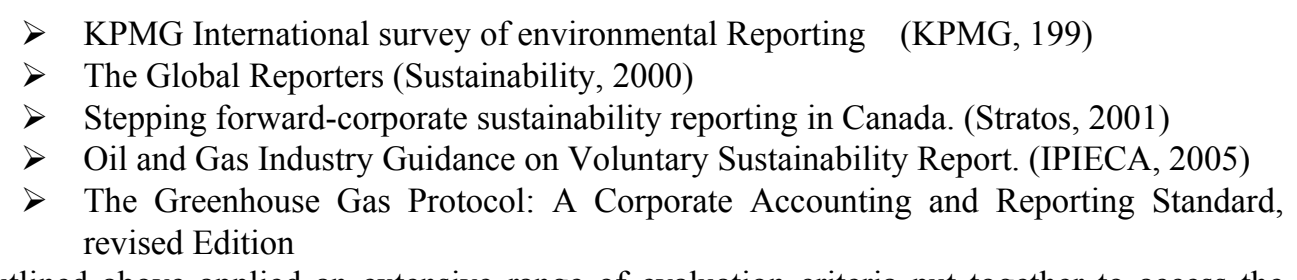

While the studies outlined above applied an extensive range of evaluation criteria put together to access the quality of environmental information, this study will only use criteria with a focus on environmental reporting system that are deemed relevant within the context of gas flaring in Nigeria. The description of evaluation criteria are as shown in table 1

The following scaling ratings were applied in accessing environmental reporting level in sampled companies:

\section{Rating/Score}

$>$ Environmental issue described in quantitative 3 and/or monetary term

$>$ Environmental issues specifically stated

Environmental issue discussed in general terms (neither quantified nor specific)

$>$ Environmental issues not in any way referred to

\section{Criteria 1: Environmental policies, objectives and target}

Four out of the sampled companies had a general statement of environmental policies and objectives within their annual report while the remaining companies had no information on environmental pollution

\section{Criteria 2: Emission Information}

Surveyed companies did not include information on gas flaring within their annual reports, however, very few companies made corporate- level general information but without information at the facility/country level. 
Only two companies provided candid acknowledgement of negative information and where it was done, it was done in general terms.

\section{Criterion 4: Environment Audit}

None of the surveyed companies had their environmental information verified by a third party

\section{Findings}

The study found out significant variations in environmental disclosure on gas flaring with no support for disclosure by any known regulation. Companies also differed in their mode of reporting which resulted in a lack of comparison of reported GHGs emission from one company to another. Additionally, while very few companies provided data on global GHGs emissions, none provided data on specific locations, facilities, and the actual impact of emission on the natural and human environment.

The study has serious implications for environmental accounting: Specific regulations in form of framework, guidance, policy and standards should be imposed on the industry making it a mandatory requirement in the following areas:

(1) Environmental Policies, Objective and targets

$>$ Companies should be required to state their environmental accounting policies and objectives

$>$ Environmental targets and achievements e.g. activities intended to reduce GHGs

(2) Emission Information emission; annual mandatory emission reduction target should be disclosed.

$>$ Companies should state in their annual report the method used in accounting for GHGs emission using either equity share or the operational control approach

$>$ The company should state the GHGs emission calculation method and tool used which would either be cross-sector or sector-specific

$>$ Regulation should require reporting of GHGs emissions at facility level and then rolled up to corporate level-furthermore, the decent rated approach should be advised where Individual facilities collect achieving data, directly calculate their GHGs emission using approved methods and then report the data at the corporate level

$>$ Companies should set a performance datum (base year emission) with which to compare current emission and specify their reason for choosing it. The base year should be chosen using either a simple year or an average of annual emission over several consecutive years. It should be stated that once a company has determined its base year policy, it should be applied consistently and should only be changed where companies undergo significant structural changes such as acquisitions, divestments, merges outstanding and in sourcing of emitting activities:

Company should state GHG emission source categories such as from stationery combustion mobile construction, process emission, fugitives emission, etc

$>$ The emission of each GHG $\left(\mathrm{CO}_{2}, \mathrm{Ch}_{4}, \mathrm{~N}_{2} \mathrm{O}\right.$, etc. $)$ should be calculated separately and then converted to $\mathrm{CO}_{2}$ equivalent on the basis of them global warning potentials

$>$ Where there is Production Sharing Agreement (PSA) the company's share of net production or Production remaining after royalty should be used as the basis for allocating emission

$>$ Where emission from gas flaring are large and the ownership of the gas and the decisions to flare it rest with the other party. Reporting company may wish to report such emission in a note to the account.

(3) Candid acknowledgment of Negative Information

$>\quad$ It should be made mandatory for companies to state their failure to achieve objectives and targets, regulatory non-compliance established against the company and fines/penalty there from.

(4) Environmental Audit

$>$ Third party environmental audit using ISO 14001 should be made mandatory for all companies operating in the petroleum sector

\section{Conclusion and Recommendations}

This study revealed significant variations in gas flaring disclosure in the Nigerian Oil and Gas sector with no legislative support for disclosure, therefore, the paper recommends accounting and reporting framework for gas flaring in line with global best practices in view of the legislative deadline for gas flaring on $31^{\text {st }}$ December, 2011. 


\section{References}

Aert, W., Cormier, D., \& Magnam, M. (2006). Intra- Industry Imitation in Corporate Environmental Reporting: An International Perspective. Journal of Accounting and Public Policy, 25(3), 299-331. doi:10.1016/j.jaccpubpol.2006.03.004, http://dx.doi.org/10.1016/j.jaccpubpol.2006.03.004

Ahmed, N. (2002). Incorporating Environmental Concerns into TQM. Production and Inventory Management Journal, 24, 25-31.

Anderson, J. (1989). Corporate Social Reporting, New York:Quorum Books.

American Petroleum Institute (2004) Compendium of Greenhouse Gas Emissions Methodologies for the Oil and Gas Industry. [Online] Available : http://www.api.org/ehs/climate/new/upload/2004. (March 10, 2011).

Azzone, G., Manzini, R., \& Noci, G.(1996). Evolutionary Trends in Environmental Reporting. Business Strategy $\begin{array}{llll}\text { and the } & \text { Environment, } & 5 & \text { 219-230. }\end{array}$ 10.1002/(SICI)1099-0836(199612)5:4<219::AID-BSE69>3.0.CO;2-K, http://dx.doi.org/10.1002/(SICI)1099-0836(199612)5:4<219::AID-BSE69>3.0.CO;2-K

Crowther, D (2000). Social and Environmental Accounting, London: Financial Times Prentice Hall.

Epstein, M.J. (1996). Measuring Corporate Environmental Performance: Best Practices for Costing and Managing an Effective Environmental Strategy. Burr Ridge, Illinois: Institute of Management Accountants and Irwin Professional Publishing.

Gray, R. (2000). Current Developments and Trends in Social and Environmental Auditing, Reporting and Attestation: A Review and Comment. International Journal of Auditing, 4(3), 247-268. DOI:10.1111/1099-1123.00316, http://dx.doi.org/10.1111/1099-1123.00316

Gray, R \& Bebbington, J. (2001). Accounting for the Environment. (2nd ed) London: Sage Publication.

Global Reporting Initiatives (2002), Sustainability Reporting Guidelines. [Online] Available: http://www.uneptie.org/scp/gri/pdf/gri_2002_guidelines.pdf ( April 25, 2011).

International Petroleum Industry Environmental Conservation Association (2002). Greenhouse Gas Emissions Monitoring and Reporting by the Aluminum Industry. [Online] Available: http://www.ipieca.org. (April 25,2011)

International Petroleum Industry Environmental Conservation Association, (2003). Compendium of Sustainability Practices and Trends for the Oil and Gas Industry. IPIECA, London. [Online] Available: http://www.ipieca.org (April 25, 2011).

International Petroleum Industry Environmental Conservation Association/American Petroleum Institute (2003).

Petroleum Industry Guidelines for Reporting Greenhouse Gas Emission. [Online] Available: http://www.ipieca.org (April 25, 2011).

International Petroleum Industry Environmental Conservation Association/American Petroleum Institute (2005). Oil and Gas Industry Guidance on Voluntary Sustainability Report. [Online] Available: http:// www.ipieca.org (April

25, 2011).

IPCC (2001), Climate Change 2002: the Scientific Basis, Cambridge University, Press Cambridge, U.K. [Online]Available: http://www.grida.no/climate/ipcc tar wg1/index.htm. (June 6, 2010)

Khanna, M., \& Anton, W. (2002). What is Driving Corporate Environmental: Opportunity or Threat? Corporate Environmental Strategy, 9 (4), 409-417. doi:10.1016/S1066-7938(02)00118-5, http://dx.doi.org/10.1016/S1066-7938(02)00118-5

KPMG (1999) KPMG International Survey of Environmental Reporting. [Online] Available: http://www.kpmg.org ( April 25, 2011).

Lars, H. \& Henrik, N. (2005). The Value Relevance of Environmental Performance. European Accounting Review, 14(1), 14.

Ngwakwe, C.C. (2009). Environmental Responsibility and Firm Performance: Evidence from Nigeria. International Journal of Humanities and Social Science, 3(2), 384-391. 
O’Donovan, G. (2002). Environmental Disclosure in the Annual Report: Extending the Applicability and Predictive Power of Legitimacy Theory. Accounting, Auditing and Accountability Journal, 15(3), 344-371. doi:10.1108/09513570210435870, http://dx.doi.org/10.1108/09513570210435870

Omofonmwan, I.S. \& Osa-Edoh, G.I. (2008). The Challenges of Environmental Problem in Nigeria. Journal of Human Ecology, 23, 53-57.

Palmer, K., Oates, K., \& Portney, P.R.(1995). Tightening Environmental Standards: the Benefit-Cost or No-Cost Paradigm?. Journal of Economic Perspectives, 4, 119-132.

Retallack, S. (2000). Economic Globalization and the Environment. Transnational Association, 4, 181-191. Shaltegger, S., Muller, K., \& Hindrichsen, H. (1996). Corporate Environmental Accounting. Chichester: Wiley \& Sons, Inc.

Stratos Inc. (2002). Stepping Forward-Corporate Sustainability Reporting in Canada. [Online] Available: http://www.stratos-sts.com/documents/2001_step (January 18, 2011).

Sustainability,(2000). The Global Reporters. [Online] Available :http:// www.globalreporting.org.

United Nation Development Programme/World Bank. (2004). Nigeria Strategic Gas Plan. Joint UNDP/World Bank Energy Sector Management Assistance Programme, ESM 279, Report 279/04. [Online] Available: http://vle.worldbank.org/bnpp/files.

Unerman, J. (2000). Reflection on Quantification in Corporate Social Reporting Content Analysis. Accounting, Auditing and Accountability Journal, 13(5), 667-681. doi:10.1108/09513570010353756, http://dx.doi.org/10.1108/09513570010353756

Uwalomwa, U., \& Uadiale, O. M. (2011). Corporate Social and Environmental Disclosure in Nigeria: A Comparative Study of the Building Materials and Brewery Industry. International Journal of Business, 6(2), 258-264.

Walley, N., \& Whitehead, B. (1994). It's Not Easy Being Green. Harvard Business Review, 72 (3),46-52.

Wilmshurst, T.D., \& Frost, G.R. (2000). Corporate Environmental Reporting: A Test of Legitimacy Theory. Accounting, Auditing and Accountability Journal, 13(1), 10-26. doi:10.1108/09513570010316126, http://dx.doi.org/10.1108/09513570010316126

World Bank (1995). Defining an Environmental Development Strategy for the Niger Delta, Volume 1, 56, Report No. 14266. [Online] Available:http:// www.brettonwoodsproject.org/institution/index.shtml.

World Resource Institute/World Business Council for Sustainable Development (2004). The Greenhouse Gas Protocol: a Corporate Accounting and Reporting Standard, Revised Edition, 2003. World Business Council for Sustainable Development and World Resources Institute, Geneva and Washington D.C. [Online] Available: http://www.epd.gov.hk/epd/english/climate_change/ca_reference.html.

Zhang, Z., \& Assuncao, L. (2043). Domestic Climate Policies and the WTO. The World Economy, 27(3), 359-386. doi:10.1111/j.1467-9701.2004.00603.x, http://dx.doi.org/10.1111/j.1467-9701.2004.00603.x 
Table 1. Description of evaluation criteria

\begin{tabular}{|c|c|}
\hline Criteria & Categories \\
\hline $\begin{array}{l}\text { (1) Environmental policies, objectives \& } \\
\text { targets }\end{array}$ & $\begin{array}{l}>\begin{array}{l}\text { Statement of environmental accounting policies and } \\
\text { objectives }\end{array} \\
>\begin{array}{l}\text { Statement of environmental objectives, targets and } \\
\text { achievements (activities intended to reduce GHG } \\
\text { emissions, annual mandatory emission reduction } \\
\text { target). }\end{array} \\
>\quad \begin{array}{l}\text { Information on actions taken, including details of the } \\
\text { nature and amount of expenditure incurred, in pursuit } \\
\text { of the identified environmental objectives. }\end{array}\end{array}$ \\
\hline (2) Emission information & $\begin{array}{l}\text { Emission data for all category of GHGs in metric } \\
\text { tonnes and in tonnes of } \mathrm{CO}_{2} \text { equivalent } \\
>\quad \text { The base year and an emissions profile over time that } \\
\text { is consistent with and clarifies the chosen policy for } \\
\text { making base year emission recalculation } \\
>\quad \text { GHG emission data for all years between the base and } \\
\text { reporting years } \\
>\quad \text { Appropriate context for any significant emission } \\
\text { changes that trigger base year emissions recalculation. } \\
>\quad \text { Specific information on the impact of emission on the } \\
\text { natural and human environment. } \\
>\quad \text { Method used in accounting for GHG emission (equity } \\
\text { or operational control approach) providing a reference } \\
\text { or link to any calculation tools used } \\
>\quad \begin{array}{l}\text { Emission data sub-divided by facilities, source types } \\
\text { and activity types. }\end{array} \\
>\quad \begin{array}{l}\text { Description of performance measured against internal } \\
\text { and external benchmarks }\end{array} \\
>\quad \text { Relevant ratio performance indicators (e.g emissions } \\
\text { for kilowatt-hour generated, tonne of material } \\
\text { production or sales } \\
>\quad \text { Information on any contractual provisions addressing } \\
\text { GHG related risk and obligations and targets }\end{array}$ \\
\hline $\begin{array}{l}\text { (3) Candid acknowledgement of negative } \\
\text { information }\end{array}$ & $\begin{array}{l}>\text { Statement of failure to achieve objectives and targets } \\
>\text { Regulatory non-compliance } \\
>\text { Fines/penalties }\end{array}$ \\
\hline (4) Environmental Audit & $\begin{array}{l}\text { External Assurance/Audit provided (e.g via ISO } \\
\text { 14001) and a copy of any verification statement of the } \\
\text { reported emission data. }\end{array}$ \\
\hline
\end{tabular}

Source: (KPMG,1999;Global Reporters, 2000;Stratos,2001; IPIECA,2005) 
Table 2. Analysis of Findings

\begin{tabular}{|c|c|c|c|c|c|c|c|c|c|c|c|}
\hline \multirow[b]{2}{*}{$\mathbf{S} / \mathbf{N}$} & \multirow{2}{*}{$\begin{array}{l}\text { Description of } \\
\text { evaluation criteria }\end{array}$} & \multicolumn{10}{|c|}{ Surveyed company } \\
\hline & & 1 & 2 & 3 & 4 & 5 & 6 & 7 & 8 & 9 & 10 \\
\hline 1 & $\begin{array}{l}\text { Statement of } \\
\text { environmental } \\
\text { accounting policies \& } \\
\text { objectives }\end{array}$ & 0 & 0 & 1 & 0 & 0 & 1 & 1 & 0 & 0 & 1 \\
\hline 2 & $\begin{array}{l}\text { Statement of } \\
\text { Environmental targets } \\
\text { and achievement }\end{array}$ & 0 & 0 & 1 & 0 & 0 & 0 & 1 & 0 & 0 & 1 \\
\hline 3 & $\begin{array}{l}\text { Information on } \\
\text { emission date for all } \\
\text { category of GHGs in } \\
\text { metric tonnes and in } \\
\text { tones of } \mathrm{CO}_{2} \\
\text { equivalent }\end{array}$ & 0 & 0 & 1 & 0 & 0 & 0 & 1 & 0 & 0 & 1 \\
\hline 4. & $\begin{array}{l}\text { Emission profile over } \\
\text { time and compared } \\
\text { with base year }\end{array}$ & 0 & 0 & 0 & 0 & 0 & 1 & 1 & 1 & 0 & 2 \\
\hline 5 & $\begin{array}{l}\text { Method used in } \\
\text { accounting for GHG } \\
\text { emission }\end{array}$ & 0 & 0 & 0 & 0 & 0 & 0 & 1 & 1 & 0 & 1 \\
\hline 6. & $\begin{array}{l}\text { Description of } \\
\text { emission data } \\
\text { sub-divided by facility }\end{array}$ & 0 & 0 & 0 & 0 & 0 & 0 & 0 & 0 & 0 & 0 \\
\hline 7. & $\begin{array}{l}\text { Description of } \\
\text { performance measured } \\
\text { against internal and } \\
\text { external benchmarks }\end{array}$ & 0 & 0 & 1 & 0 & 0 & 1 & 1 & 1 & 0 & 1 \\
\hline 8. & $\begin{array}{l}\text { Ratio performance } \\
\text { indicators }\end{array}$ & 0 & 0 & 0 & 0 & 0 & 0 & 1 & 0 & 0 & 1 \\
\hline 9. & $\begin{array}{l}\text { Contractual provision } \\
\text { addressing GHG } \\
\text { related risk \& } \\
\text { obligation }\end{array}$ & 0 & 0 & 1 & 0 & 0 & 1 & 1 & 0 & 1 & 1 \\
\hline 10 & $\begin{array}{l}\text { Statement of failure to } \\
\text { achieve objectives \& } \\
\text { targets }\end{array}$ & 0 & 0 & 1 & 0 & 0 & 0 & 0 & 0 & 0 & 1 \\
\hline 11 & $\begin{array}{l}\text { Statement of } \\
\text { non-compliance to } \\
\text { regulation established } \\
\text { against the company }\end{array}$ & 0 & 0 & 1 & 0 & 0 & 1 & 0 & 0 & 0 & 1 \\
\hline 12 & $\begin{array}{l}\text { Fines and Penalty } \\
\text { established against the } \\
\text { company }\end{array}$ & 0 & 0 & 0 & 0 & 0 & 0 & 0 & 0 & 0 & 0 \\
\hline 13 & $\begin{array}{l}\text { Environmental Audit } \\
\text { (ISO 14001) }\end{array}$ & 0 & 0 & 0 & 0 & 0 & 0 & 0 & 0 & 0 & 0 \\
\hline
\end{tabular}

Source: Field Survey, 2011 